\title{
CHARACTERIZATION AND EVOLUTION OF ORE-FORMING FLUIDS AT FAZENDA BRASILEIRO GOLD MINE, RIO ITAPICURU GREENSTONE BELT, BA
}

\author{
ROBERTO PEREZ XAVIER*
}

\begin{abstract}
Fluid inclusion studies by microthermometry and Raman spectroscopy carried out on the main hosts of the gold mineralizations at Fazenda Brasileiro Mine, southern part of Rio Itapicuru greenstone belt define the mineralizing fluids as relatively dense $\left(0.85-0.95 \mathrm{~g} / \mathrm{cm}^{3}\right)$ and hot $\left(>400^{\circ} \mathrm{C}\right)$ solutions composed essentially of $\mathrm{CO}_{2}$ (89.7-85.3 mole\%) and minor amounts of $\mathrm{CH}_{4}$ and $\mathrm{N}_{2}$, which gradually evolved to more aqueous fluids $\left(40\right.$ to 62.5 moles $\% \mathrm{H}_{2} \mathrm{O}$ ) of low salinity $(<10 \mathrm{eq}$. wt $\% \mathrm{NaCl}$ ) at lower temperatures $\left(250-300^{\circ} \mathrm{C}\right)$. The isochores of the carbonic and $\mathrm{H}_{2} \mathrm{O}-\mathrm{CO}_{2}$ fluids and the temperature of total homogeneization combined with geothermometric data on the are paragenesis, point to at least two periods of gold deposition: $1.380-419^{\circ} \mathrm{C}$ and $2.2-3.2 \mathrm{~kb}$ in the quartzofeldspathic and arsenopyrite- pyrite quartz veins and $2.270-300^{\circ} \mathrm{C}$ and $1.2-1.4 \mathrm{~kb}$ in the massive quartz vein. Based on experimental work on the solubility of gold complexes, chemical characteristics of mineralizing fluids, ore paragenesis and $\mathrm{Au} / \mathrm{Ag}$ ratio, it was possible to speculate that the transport of gold occurred mainly by reducing (high $\left.\Sigma \mathrm{H}_{2} \mathrm{~S} / \Sigma \mathrm{SO}_{4}\right)$, slightly neutral to alkaline solutions, as thio-complexes such as $\mathrm{Au}(\mathrm{HS})_{2}, \mathrm{HAu}(\mathrm{HS})_{2}^{\circ}$ or $\mathrm{Au}_{2}(\mathrm{HS})_{2} \mathrm{~S}^{-2}$. In the earliest stage of mineralization conditions of gold deposition were probably attained due to fluid/rock reactions which led to a decrease in the activity of $\mathrm{S}^{-2}$ by precipitating sulphides (arsenopyrite, pyrite, pyrrhotite, etc). The predominance of the $\mathrm{H}_{2} \mathrm{O}$ regime over the $\mathrm{CO}_{2}$ regime in the latest stage might have been the cause of $\mathrm{CO}_{2}$ dilution, decrease in $\mathrm{pH}$ and oxidation and, as a consequence, the precipitation of gold. The fluid inclusion data also suggest a metamorphic origin for the mineralizing fluids, most likely through the devolatilization of the basal sequences of the volcano-sedimentary pile. The devolatilization process would be able produce low salinity, $\mathrm{H}_{2} \mathrm{O}-\mathrm{CO}_{2}$ fluids which would later migrate through favourable structural sites and deposit their metal content.
\end{abstract}

RESUMO CARACTERIZAÇÃO E EVOLUÇÃO DOS FLUIDOS MINERALIZANTES NA MINA DE OURO FAZENDA BRASILEIRO, GREENSTONE BELT DO RIO ITAPICURU, BA, BRASIL. Os estudos de inclusōes fluidas por microtermometria e espectroscopia Raman nas hospedeiras das mineralizaçóes auríferas da Mina Fazenda Brasileiro, localizada na parte sul do greenstone belt do Rio Itapicuru, permitiram definir os fluidos mineralizantes como soluçőes quentes $\left(>400^{\circ} \mathrm{C}\right)$, de densidade relativamente alta $\left(0,85-0,90 \mathrm{~g} / \mathrm{cm}^{3}\right)$, inicialmente compostas por $\mathrm{CO}_{2}(89,7-85.4$ moles\%) e pequenas quantidades de $\mathrm{CH}_{4} \mathrm{e} \mathrm{N}_{2}$, que evoluem com o abaixamento da temperatura $\left(250-300^{\circ} \mathrm{C}\right)$ para soluçōes que se tornam gradativamente mais aquosas (de 40 a 62,5 moles\% de $\mathrm{H}_{2} \mathrm{O}$ ) e de baixa salinidade $(<10$ eq. $\%$ em peso $\mathrm{NaCl}$ ). As isócoras dos fluidos carbônicos e aquocarbônicos e as temperaturas de homogeneizaçấo total, combinadas com dados de geotermometria fornecidos pela paragênese mineral, sugerem a existência de pelo menos dois períodos de deposição do ouro: 1. $380-419^{\circ} \mathrm{C} \mathrm{e} 2,2-3,2 \mathrm{~kb}$ na brecha quartzo-feldspática e veio de quartzo com arsenopirita e pirita e 2. $270-300^{\circ} \mathrm{C}$ e $1,2-1,4 \mathrm{~kb}$ no veio de quartzo maciço. Baseado em estudos experimentais da solubilidade de complexos auríferos, nas características químicas dos fluidos mineralizantes, na paragênese de minério e na razão $\mathrm{Au} / \mathrm{Ag}$, presume-se que o ouro deva ter sido transportado como tiocomplexos do tipo $\mathrm{Au}(\mathrm{HS}) \overline{2}, \mathrm{HAu}(\mathrm{HS})_{2}^{8}$ ou $\mathrm{Au}_{2}(\mathrm{HS})_{2} \mathrm{~S}^{-2}$ em soluçóes redutoras (razẫo $\Sigma \mathrm{H}_{2} \mathrm{~S} / \Sigma \mathrm{S} \mathrm{O}_{4}$ alta) e com $\mathrm{PH}$ em torno da neutralidade ou levemente alcalino. Nos estágios mineralizantes iniciais, condiçōes para a precipitação do ouro foram atingidas devido às reaçöes fluido/rocha que levaram ao decréscimo na atividade de $\mathrm{S}^{-2} \mathrm{com}$ a precipitação dos sulfetos metálicos (arsenopirita, pirita, pirrotita etc). Nos estágios de colocação dos veios de quartzo tardios acredita-se que a deposição do ouro tenha ocorrido pela introdução de $\mathrm{H}_{2} \mathrm{O}$ no sistema, causando a diluição de $\mathrm{CO}_{2}$, diminuição do $\mathrm{pH}$, oxidação e conseqüente desestabilização dos complexos transportadores desté metal. A origem metamórfica desses fluidos mineralizantes é também indicada pelo estudo de inclusőes fluidas, entendendo-se que possam ser derivados a partir de processos de devolatilização das seqüências mais basais do greenstone belt, capazes de produzir fluidos carbônicos e aquocarbônicos de baixa salinidade, que posteriormente migram através de sítios estruturais favoráveis, causam fraturamento hidráulico e depositam seu conteúdo metálico.

INTRODUCTION Fluid inclusions are tiny samples of fluids trapped in minerals either during or after their crystallization. For them, information about several physicochemical parameters such as composition, salinity, density, temperature, and pressure of formation may be determined.

Fluid inclusion studies carried out in greenstone belt gold deposits have shown that gold is deposited by low salinity ( $<5$ eq. wt\% $\mathrm{NaCl}$ ), $\mathrm{H}_{2} \mathrm{OCO}_{2}$ solutions with temperatures varying from $280^{\circ}$ to $500^{\circ} \mathrm{C}$ and pressures between 0.8 and $5.0 \mathrm{~kb}$ (Phillips \& Groves 1983, Smith et al. 1984, Brown \& Lamb 1986, Groves \& Phillips 1987).

The purpose of this work is to determine the physico-chemical characteristics, evolution, and nature of the gold-bearing fluids, through a systematic fluid inclusion investigation in several mineralized samples from the Fazenda
Brasileiro Gold Mine, in the southern portion of the Rio Itapicuru greenstone belt, one of the main primary gold producing areas in Brazil. Despite the difficulty to correlate the inclusion fluids studied to the actual gold-depositing fluids, this word, also attempts to provide valuable data to the understanding of the processes by which the gold content of the fluids was deposited.

GEOLOGICAL SETTING In the northern portion of the São Francisco Craton in the State of Bahia, a group of supracrustal rocks occurring as infolds and surrounding oval-granite-gneiss domes was defined and later known as the Rio Itapicuru greenstone belt, of Archaean or Lower Proterozoic age (Fig. 1) (Kishida 1979, Teixeira 1984).

According to Kishida (op. cit.) and Kishida \& Riccio

* Departamento de Metalogênese e Geoquímica, Instituto de Geociências Unicamp. Caixa Postal 6152, CEP 13081, Campinas, SP, Brasil. Present address: Department of Geology, University of Southampton, Southampton SO9 5NH, United Kingdom 


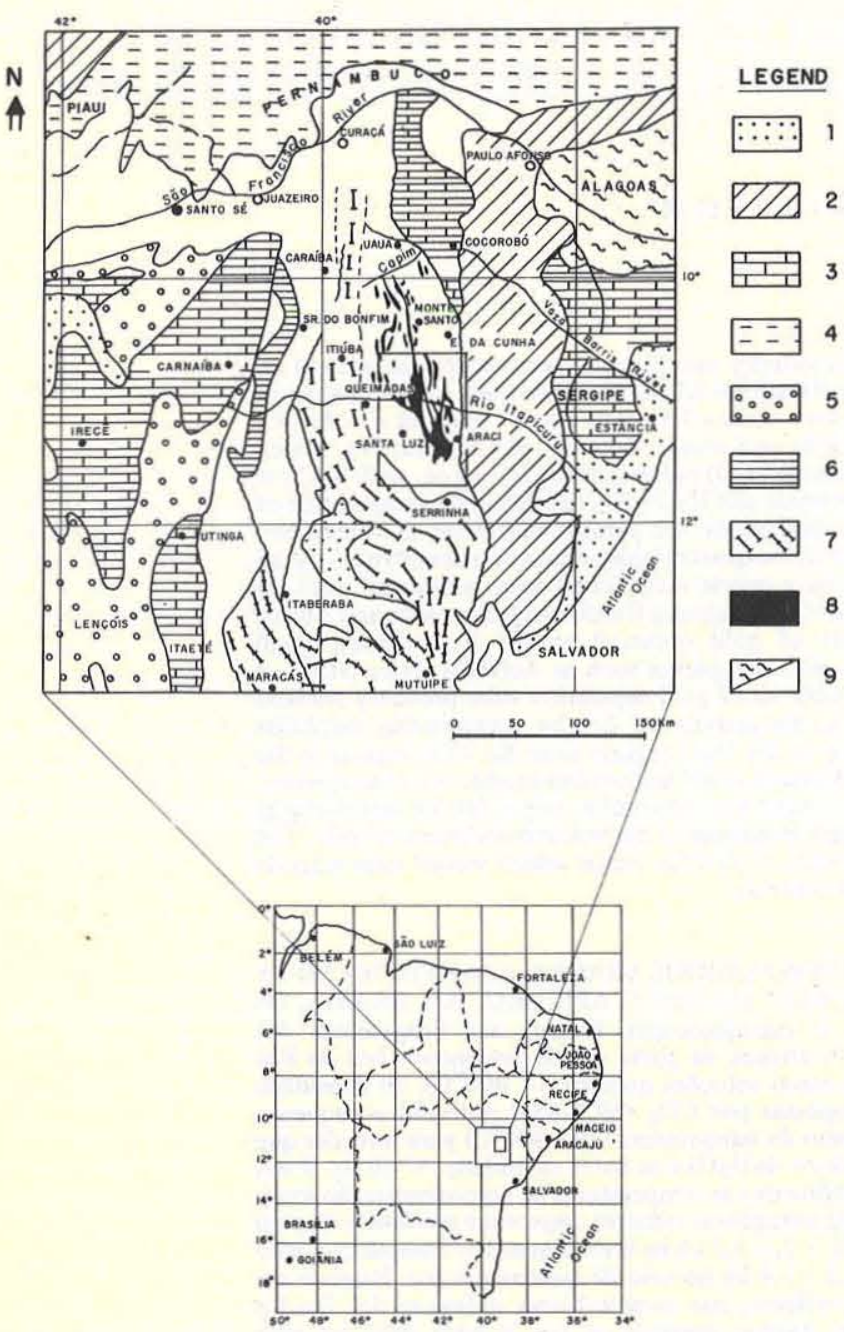

Figure 1 -Simplified geology of the northern portion of Bahia State and location of the Rio Itapicuru greenstone belt (inner rectangle): 1. Cenozoic cover; 2. phanerozoic sediments; 3. Säo Francisco Supergroup; 4. Nordeste Fold Belt; 5. Espinhaço Supergroup; 6. Jacobina Group; 7. granulite complex; 8. greenstone belts; 9. gneiss migmatite complex (Teixeira et al. 1982)

(1980), these supracrustal rocks may be divided into three distinct domains: 1. Mafic Volcanic Domain (MVD), 2. Felsic Volcanic Domain (FVD), and 3. Sedimentary Domain (SD) (Fig. 2).

The MVD is dominant throughout the area, comprising massive and pillowed metabasalts of tholeiitic affinity and minor interlayered chemical sediments (iron formation and cherts).

In contrast with these mafic sequences, the FVD is more restricted in area and consists of a rock assemblage of calc-alkalic composition with predominance of pyroclastics (tuffs and agglomerates), andesitic-dacitic lavas, fragmentary epiclastics (sandstones, siltstones, and shales), and chemical sedimentary interlayerings.

The SD forms thick individualized horizons in the upper part of this volcano-sedimentary sequence and is mainly composed of arkoses, conglomerates, greywackes, and pelites.

The intrusive rock suites include: 1. the granite-gneiss domes with granites and granodiorites in their central portion and tonalites at their margins; 2 . late-tectonic subvolcanic bodies of quartz feldspathic porphyritic rocks, and 3 .

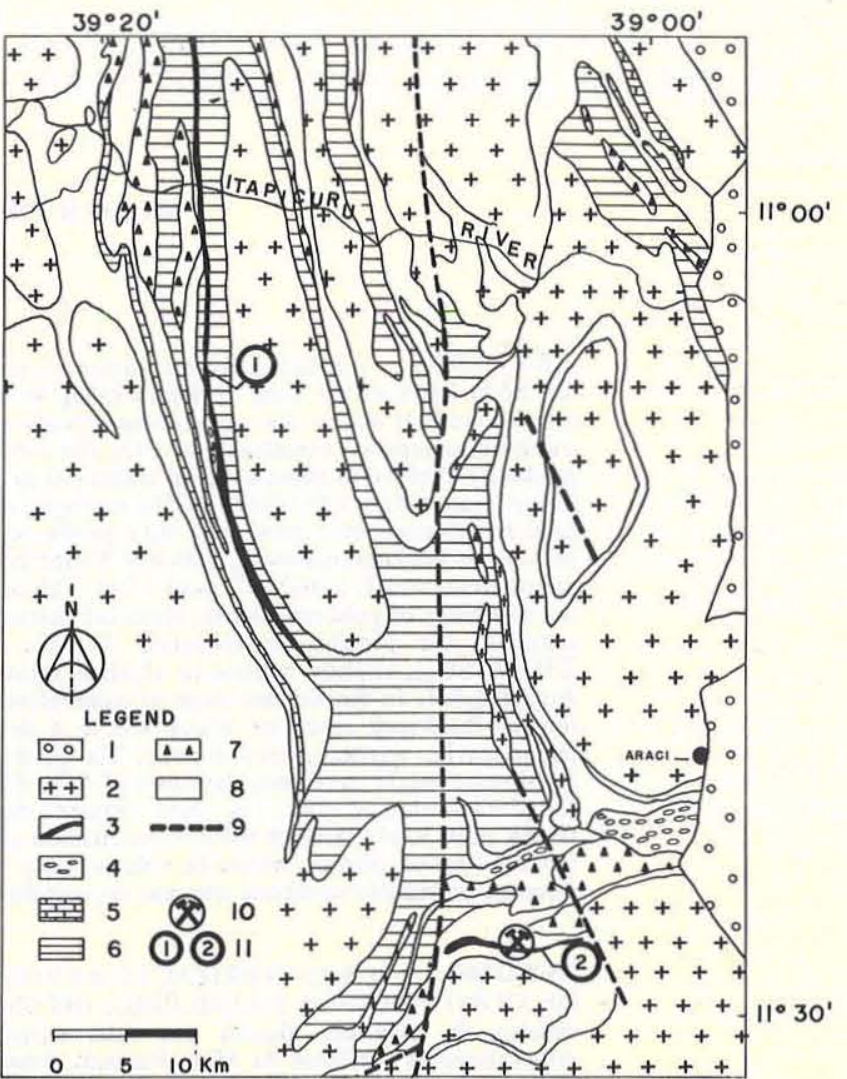

Figure 2 - Geology of the central to southern portion of the Rio Itapicuru Greenstone Belt: 1. phanerozoic sediments (Tucano Basin); 2. gneisses, migmatites, and granites: 3. mafic intrusives; 4. metaconglomerates; 5. dolomitic marble; 6. Sedimentary Domain; 7. Felsic Volcanic Domain; 8. Mafic Volcanic Domain; 9. fault/shear zones; 10. normal fault; 10. Fazenda Brasileiro gold mine; 11. (1) Mansinha belt and (2) Weber belt (Teixeira et al. 1988)

gabbroic dykes and sills which occur as interlayering within the MVD and SD, or traverse the granite-gneiss domes (Kishida 1979, Teixeira et al. 1982).

Silva (1983) recognized three distinct metamorphic events within the supracrustal sequence. The $M_{1}$ event was interpreted as seafloor metasomatism on part of the volcanic rocks, producing spilites and keratophyres. The $\mathrm{M}_{2}$ event was related to intrusions of granite-gneiss domes which resulted in a metamorphic zoning within the supracrustal rocks, grading from greenschist facies to amphibolite facies. The effect of the $M_{3}$ event is restricted to contact aureoles around late-tectonic intrusives.

Based on mineral parageneses and mineral chemistry, Silva (op. cit.) estimated the P-T values from the metamorphic events as follows: $M_{1}=0.2 \mathrm{~kb} /<400^{\circ} \mathrm{C} ; \mathrm{M}_{2}=$ $2-4 \mathrm{~kb} / 400-600^{\circ} \mathrm{C}$, and $\mathrm{M}_{3}=<2 \mathrm{~kb} / 500-600^{\circ} \mathrm{C}$.

The structural pattern shown by the supracrustal sequence is very complex and the knowledge of the styles of deformation is not homogeneous throughout the greenstone belt. In the southern portion, Teixeira (1984) defined four phases of ductile deformation and one corresponding to a brittle tectonic regime whereas in the western part; studies are still in progress, with emphasis on shear zones (Silva \& Matos 1987).

THE GEOLOGY OF THE FAIXA WEBER AND THE
GOLD MINERALIZATION AT BRASILEIRO MINE Since 1974, prospecting for gold carried out by Rio Doce Geologia e Mineração S.A. 
(Docegeo) has shown several anomalies associated with basalts of the MVD, andesites of the FVD, subvolcanic bodies, and gabbroic sills. One of the most important discoveries has been the Faixa Weber orebodies located at the extreme south of the Rio Itapicuru greenstone belt.

The local stratigraphy is considered to be composed from the bottom to the top of the following lithological associations (Fig. 3) (Teixeira et al. 1988):

1. The Fazenda Canto unit turbidite sequence, composed mainly of fine-grained carbonaceous metasediments, with alternating well laminated metargillite, metasiltstone, and interlayerings of black metachert and metagreywacke.

2. The Fazenda Brasileiro unit consisting of gabbroic rocks associated with a magnetite-bearing quartz-chlorite schist ("magnetic schist") and discontinuous and strongly deformed lenticular shaped quartz-feldspathic bodies which are referred as "quartz-feldspathic" breccia. Based on major and trace element geochemistry, Montes Lopes (1982) suggested a calc-alkalic affiliation for the gabbroic rocks and a carbonate facies iron formation nature for the "magnetic schist". In the light of new geochemical, petrological, and structural data, Teixeira (op. cit.) reinterpreted the Fazenda Brasileiro unit as representing a metamorphosed and folded differentiated sill which consists of a basal gabbro which grades upwards to an iron-rich gabbro ("magnetic schist") with lenses of prophyritic anorthosite at the top. In this interpretation, the iron-rich metagabbro appears at the north and south of the basal gabbro due to repetition by folding (Fig. 3).

3. The Riacho do Incó unit, composed of tholeiitic basalt flows with interlayered sedimentary rocks and metagabbro sills.

Fazenda Brasileiro is one of a series of gold deposits along the Faixa Weber whose production reached about $1,000 \mathrm{~kg}$ of gold in october 1986 by open-pit mining and heap-leaching of the weathered ore. At present, the transition from open-pit to underground mining is in progress and a selected ore block provided an estimate of $7.9 \times 10^{6}$ ton of ore, with an average grade of $8 \mathrm{~g} /$ ton (Teixeira $o p$. cit.).

The major orebodies at Fazenda Brasileiro are found within the "magnetic schist" (iron-rich metagabbro), associated with crosscutting carbonate-quartz-albite-suphide veins and quartz veins a few millimeters to a decimeter thick (Teixeira et al. op. cit.). In the former, gold is mainly found as inclusions or along fractures in sulphide $\mathrm{cr}$, stals, notably arsenopyrite, and pyrite whereas' in the latter gold occurs disseminated.
Both vein types are enveloped by zones of hydrothermal alteration in which the metamorphic assemblage of greenschist facies has been replaced by new mineral associations with a distinct zonation (Marimon et al. 1986). Towards the veins, chlorite gives place to albite and carbonate, magnetite is replaced by pyrite and arsenopyrite, and less commonly there is an increase in biotite with a decrease in quartz.

\section{RESULTS Fluid Inclusion Data ANALYTICAL PROCEDURES Microthermometry is the most} frequently used non-destructive method in the analysis of inclusion fluids in minerals. It involves the observation of phase changes at low and ligh temperatures which can be attained by a heating/freezing stage mounted on a normal petrographic microscope, The microthermometry apparatus used in this work is for Chaixmeca type, whose major feature is the capability of readily achieving temperatures between $-190^{\circ} \mathrm{C}$ and $600^{\circ} \mathrm{C}$ by combining a system of circulating refrigerated liquid $\mathrm{N}_{2}$ and a resistive heater (Poty et al. 1976).

Doubly-polished sections, 50 to $60 \mu \mathrm{m}$ thick, were made from the quartz-feldspathic breccia, quartz-albite-sulphide vein and quartz vein, all mineralized samples collected from the Fazenda Brasileiro sequence. These sections were studied under the microscope to select areas of suitable inclusions for microthermometry. Then, small chips $(0.5 \mathrm{~cm} \times 0.5 \mathrm{~cm} \times 0.5$ $\mathrm{cm}$ ) containing the selected areas were detached from the doubly-polished sections and inserted in the heating/freezing stage.

The calibration of the microthermometry apparatus was obtained for low temperature runs using a natural $\mathrm{H}_{2} \mathrm{O}-\mathrm{CO}_{2}$ inclusion in quartz, from the Tessiner Alps (Switzerland), with the previous knowledge of its $\mathrm{CO}_{2}$ melting point $\left(-56.6^{\circ} \mathrm{C}\right)$. Potassium dichromate $\left(\mathrm{tf}=398^{\circ} \mathrm{C}\right)$ from Merck P.A. was used to calibrate the stage for high temperatures. These procedures indicated that the average precision of the stage may be placed within $\pm 0.2^{\circ} \mathrm{C}$ and $\pm 0.5^{\circ} \mathrm{C}$ for low and high temperature intervals respectively. Temperatures measured with the heating/freezing stage were: melting of $\mathrm{CO}_{2}\left(\mathrm{TmCO}_{2}\right)$, melting of ice (Tmi), melting of clathrates $(\mathrm{TmCl}), \mathrm{CO}_{2}$ homogenization $\left(\mathrm{ThCO}_{2}\right)$, and homogenization (Th). Furthermore, several inclusions were also submitted to Laser Raman Microprobe (LRM) to supplement information provided by microthermometry.

In the LRM technique, a monochromatic laser beam is

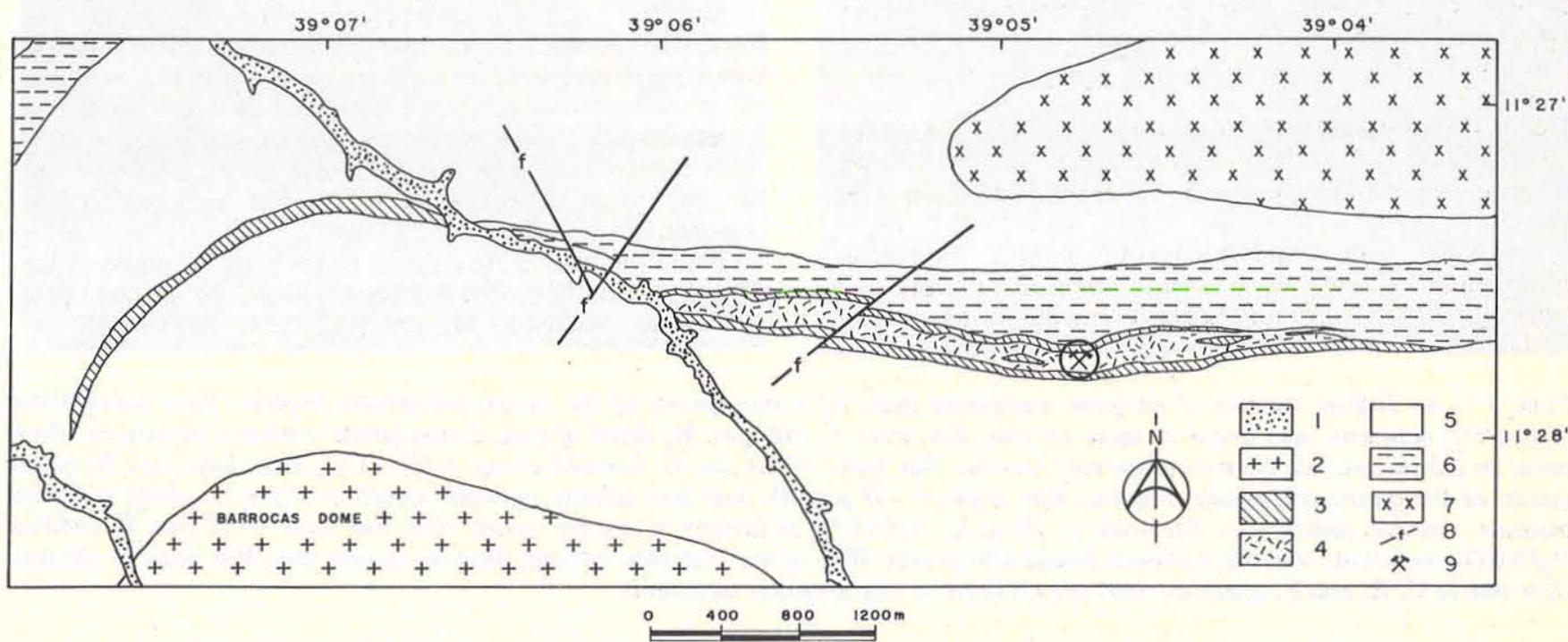

Figure 3 - Geological map of the Weber Belt: 1. alluvium; 2. granodiorite; Fazenda Brasileiro Sequence: 3. magnetic schist; 4. intermediary unit; 5 . Riacho do Incó Sequence (tholeiitic metabasalts); 6. Fazenda Canto Sequence (metaturbidites); 7. calc-alkaline metadacite and metarhyodacite of the Felsic Volcanic Domain; 8. faults; 9. Fazenda Brasileiro gold mine (Teixeira et al. 1988) 

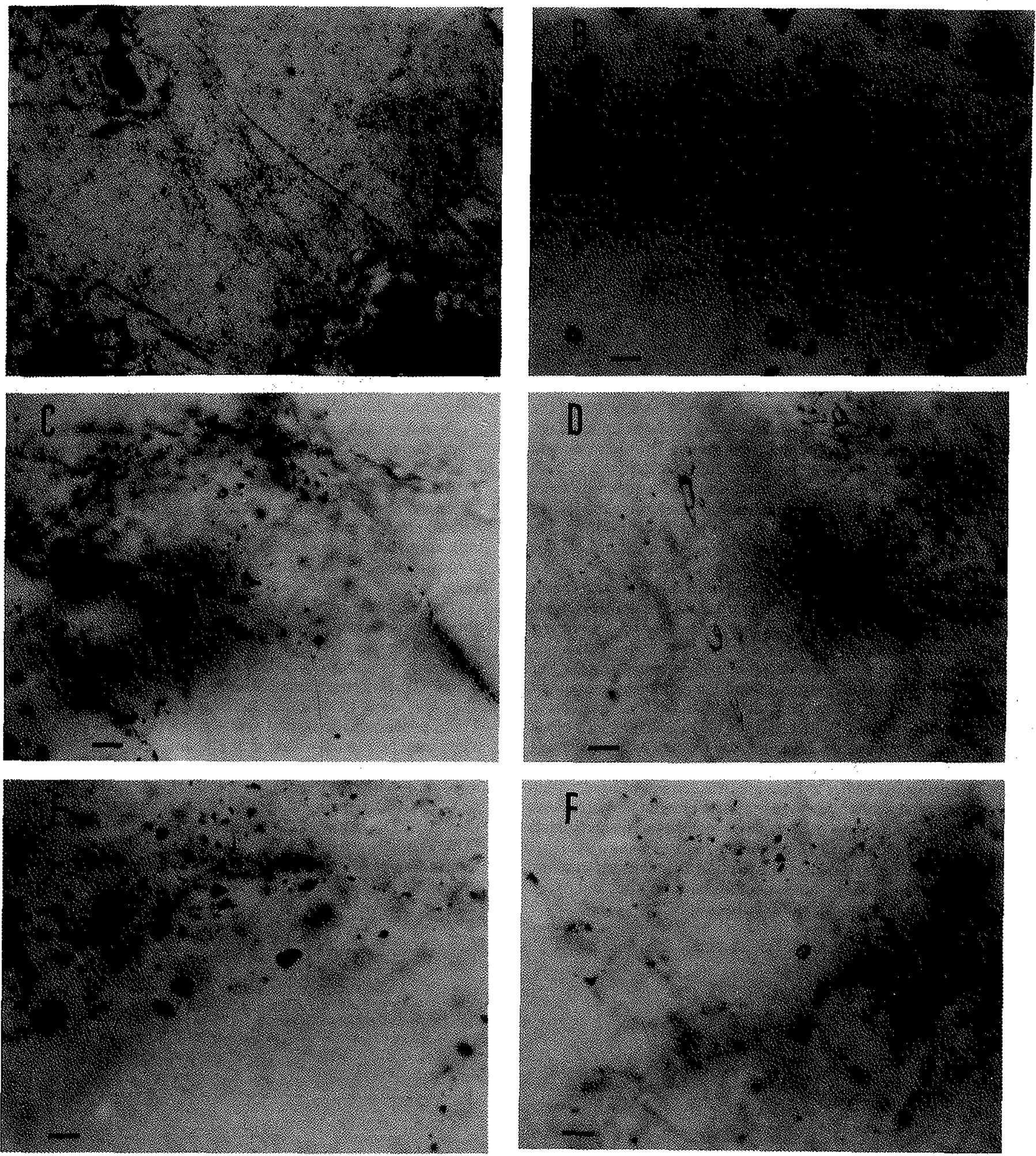

Plate 1 - A. Diffuse swarms of carbonic inclusions (type A) within quartz of the quartz-feldsphatic breccia. Very subordinate $\mathrm{H}_{2} \mathrm{O}-\mathrm{CO}_{2}$ inclusions also occur in these groups. Bar scale $=100 \mu \mathrm{m} ; \mathbf{B}$. detail of typical monophase carbonic inclusions which occur in diffuse swarms, Quartz-feldsphatic breccia. Bar scale $=20 \mu \mathrm{m} ;$. C. isolated group of $\mathrm{H}_{2} \mathrm{O}_{-\mathrm{CO}}$ inclusions (type B) within quartz of the quartz-feldsphatic breccia. Bar scale $=20 \mu \mathrm{m} ; \mathbf{D}$. late low salinity aqueous inclusions (type C) along a healed fracture. Massive quartz vein. Bar scale $=10 \mu ; \mathbf{E} . \mathrm{H}_{2} \mathrm{O}-\mathrm{CO}_{2}$ inclusions in massive quartz vein: Bar scale $=20 \mu m ; \mathbf{F}$, isolated $\mathrm{H}_{2} \mathrm{O}-\mathrm{CO}_{2}$ inclusion, with the carbonic phase filling over $90 \%$ of the inclusion volume. Massive quartz vein. Bar scale $=20 \mu m$. Note that in $\mathbf{C}, \mathbf{E}$, and $\mathbf{F}$, quartz crystals are outlined by intergranular inclusions

focused by a microscope objective into an individual phase within inclusion cavity, allowing Raman spectroscopy on a microscopic scale. The Raman effect is the shift in frequency that the laser light undergoes during inelastically scattered light emitted by the sample. Raman scattering is of analytical interest, since it is caused by a component-specific molecular 
vibrational and rotational phenomena in the sample (Wopenka \& Pasteris 1986). The LRM has been used effectively in the study of fluid inclusions to identify different kinds of volatiles (e.g. $\mathrm{CO}_{2}, \mathrm{CO}, \mathrm{H}_{2} \mathrm{~S}, \mathrm{CH}_{4}, \mathrm{C}_{2} \mathrm{H}_{6}, \mathrm{~N}_{2}$ ) in metamorphic and igneous rocks as well as hydrothermal ore deposits (Rosasco et al. 1975, Dhamelincourt et al. 1979, Xavier 1987). Simple ionic species, like $\mathrm{Ca}^{+2}, \mathrm{Na}^{+}, \mathrm{K}^{+}, \mathrm{Cl}$, however, are not appreciably Raman active in pure crystalline form or in aqueous solutions, although there have been several attempts to obtain such data (Dubessy et al. 1982).

The LRM used to analyse the carbonic phase of the investigated inclusions in the present work was of Dilor Microdil Instruments, as described by Dhamelincourt et al. (op. cit.). The precision of the results was estimated around 10 to $20 \%$ of the obtained values.

TYPES OF FLUID INCLUSIONS Three types of inclusions were recognized.

Type $A$ inclusions are single-phase, composed mainly of $\mathrm{CO}_{2}$ and occur in large groups without planar orientation. They show negative crystal contours (polygonal or diamond shaped) or irregular shapes, ranging from $5 \mu \mathrm{m}$ to $20 \mu \mathrm{m}$. They are classified as monophase carbonic inclusions (Pl. 1B).

Type $B$ inclusions consist of two discernible phases at room temperature, $\mathrm{H}_{2} \mathrm{O}$ and $\mathrm{CO}_{2}$. The volume ratio between these two phases is variable, but the $\mathrm{CO}_{2}$ phase is generally dominant and occupies most of the volume cavity of the inclusion. They are $5 \mu \mathrm{m}$ to $20 \mu \mathrm{m}$ in size, show negative crystal contours and can be found coexisting with type A inclusions, isolated or even in small groups in the interior of quartz crystals. They are classified as mixed $\mathrm{H}_{2} \mathrm{O}-\mathrm{CO}_{2}$ inclusions (PI. 1CES).

Type $C$ inclusions are dominant aqueous two-phase, containing liquid and vapor phases at room temperature $\left(\mathrm{H}_{2} \mathrm{O}_{1} / \mathrm{H}_{2} \mathrm{O}_{\mathrm{v}}>0.9\right)$. Most of type $\mathrm{C}$ inclusions are in the range from $2 \mu \mathrm{m}$ to $10 \mu \mathrm{m}$ and show variable shapes. In the quartz-feldspathic breccia and sulphide-bearing vein, these inclusions appear mainly along healed fractures and are most likely to represent late aqueous late fluids. In the quartz vein, however, they occur either isolated or in groups with planar arrays, forming patches within the more abundant type B inclusions.

Translucent and opaque minerals in inclusions are rare but when present they do not seem to be true daughter minerals, but accidentaly trapped phases. This hypothesis is supported by several lines of evidence: a. only a few inclusions contain these solid phases; b. there are no uniform phase ratios in those inclusions which contain the solid; and c. they do not dissolve on heating (Roedder 1984).

\section{MICROTHERMOMETRY AND RAMAN SPEC-}

TROSCOPY Previous microscopy provided the basis for a selection of inclusions for microthermometric investigations.

This helped to identify and select inclusions whose fluid content has preserved some of the main characteristics of the mineralizing fluids responsible for the gold transport and deposition. Thus, some of the factors which were taken into account are: a. mode of occurrence - only relatively isolated inclusions or isolated group of inclusions were considered as reliable; and b. no evidence of leakage or necking-down.

The melting temperatures of $\mathrm{CO}_{2}\left(\mathrm{TmCO}_{2}\right)$ in types $\mathrm{A}$ and $B$ inclusions in the quartz-feldspathic breccia, quartz-albite-sulphide vein, and quartz vein range from $-60.3^{\circ} \mathrm{C}$ to $-57.0^{\circ} \mathrm{C}$ (Fig. 4). This conspicuous depression of $\mathrm{TmCO}_{2}$ in relation to the melting temperature of pure $\mathrm{CO}_{2}$ $\left(-56.6^{\circ} \mathrm{C}\right)$ indicates that the inclusions fluids are not composed solely of $\mathrm{CO}_{2}$, but there might be minor amounts of other components dissolved in their carbonic phase.

Several inclusions were submitted to Laser Raman Microprobe analysis and confirmed the presence of variable

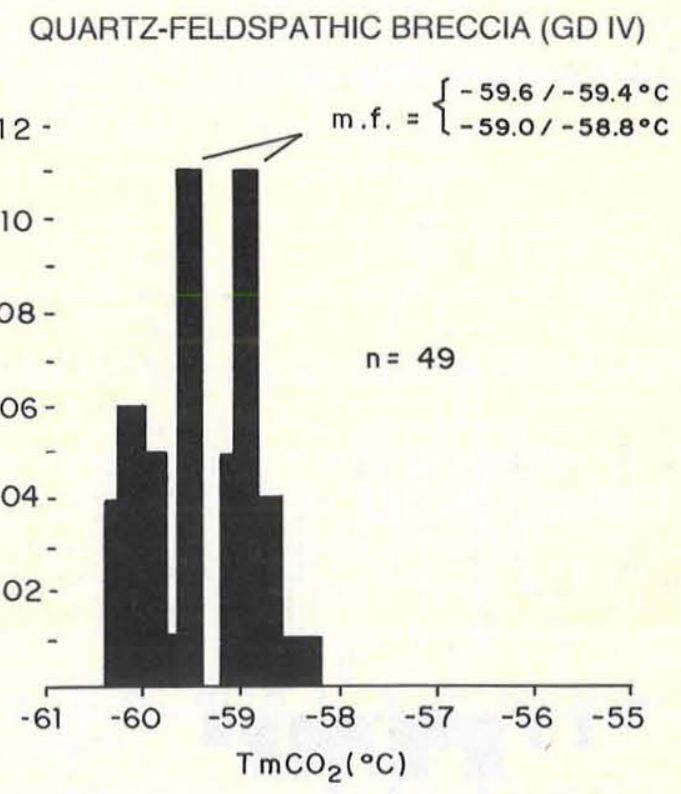

ARSENOPYRITE-PYRITE-QUARTZ VEIN (SB 8OII)

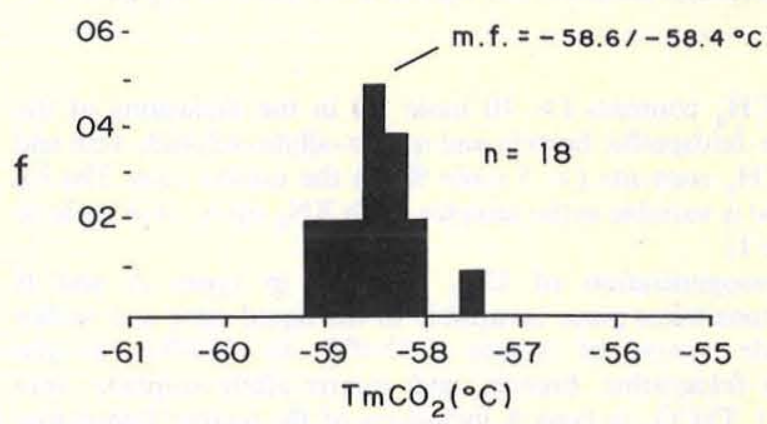

MASSIVE QUARTZ VEIN (SB 801 )

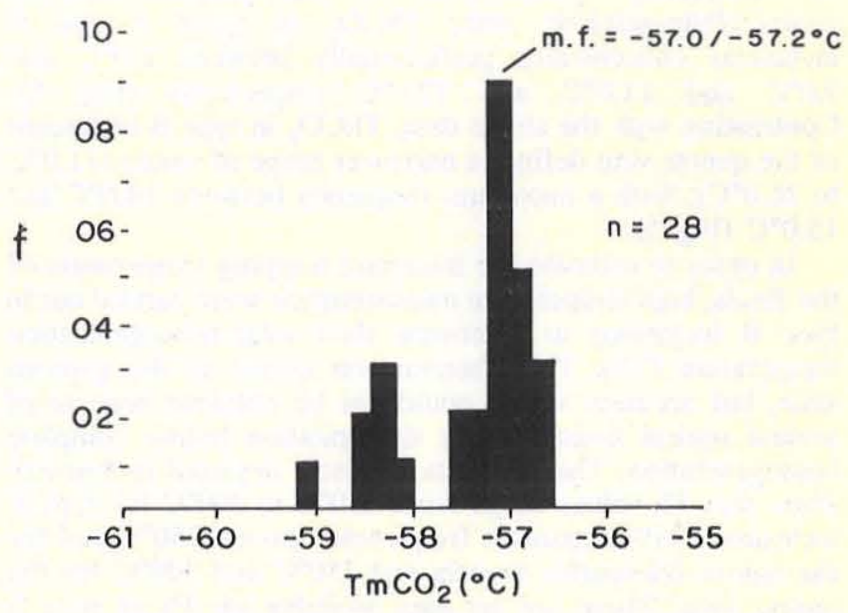

Figure 4- Histograms of temperature of $\mathrm{CO}_{2}\left(\mathrm{TmCO}_{2}\right)$ for carbonic (type A) and $\mathrm{H}_{2} \mathrm{O}-\mathrm{CO}_{2}$ (type B) inclusions in minealized samples. $\mathbf{n}=$ number of inclusions measured; $\mathbf{f}=$ frequency; $\mathbf{m f}=$ maximum frequency

amounts of $\mathrm{N}_{2}$ and $\mathrm{CH}_{4}$, as the components responsible for the above $\mathrm{TmCO}_{2}$ depression (Table 1). LRM data revealed 


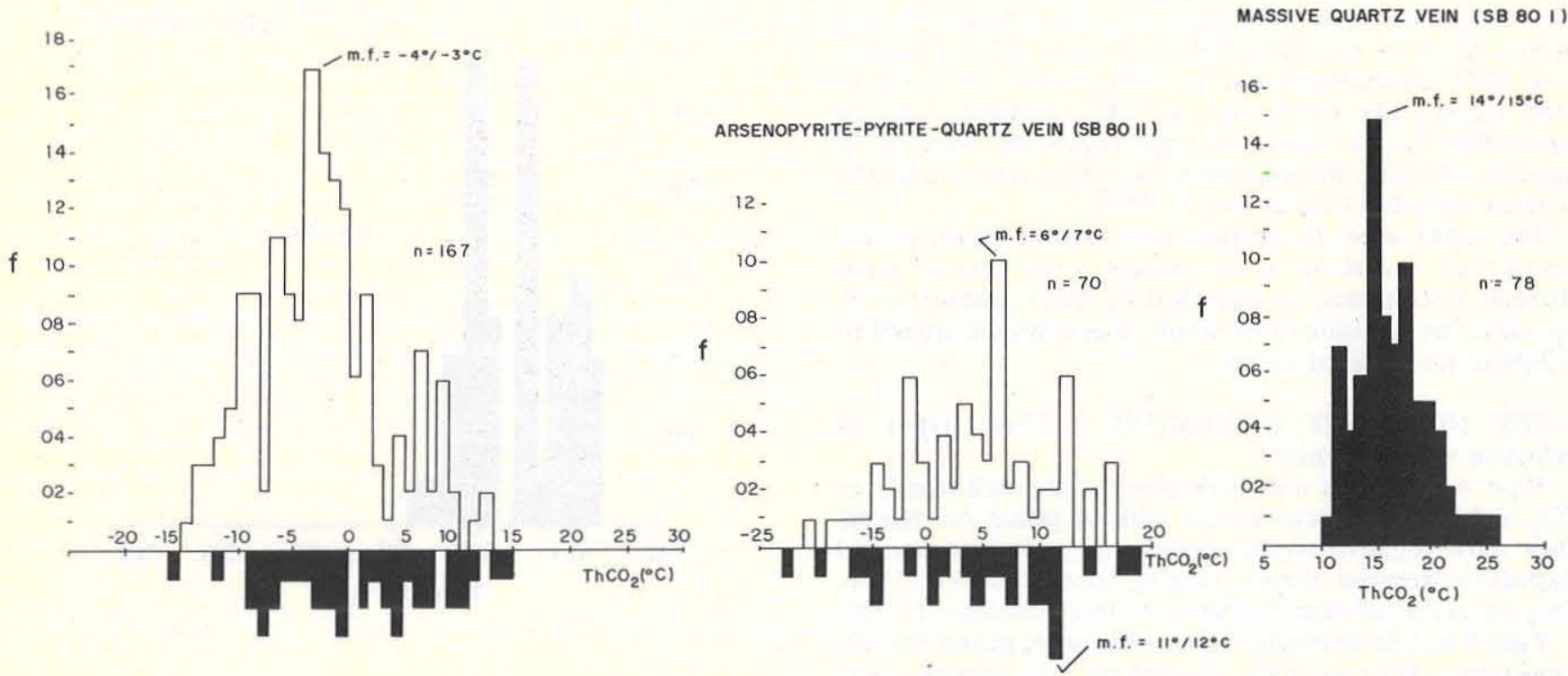

Figure 5-Histograms of melting temperature of $\mathrm{CO}_{2}\left(\mathrm{ThCO}_{2}\right)$ for carbonic (type A, blank) and $\mathrm{H}_{2} \mathrm{O}-\mathrm{CO}_{2}$ (type B, dark) inclusions in mineralized samples. The legend is the same as in figure 4

high $\mathrm{CH}_{4}$ contents ( $>10$ mole $\%$ ) in the inclusions of the quartz-feldspathic breccia and quartz-albite-sulphide vein and low $\mathrm{CH}_{4}$ contents $\left(>5\right.$ mole \%) in the quartz vein. The $\mathrm{N}_{2}$ content is variable in the samples, with $\mathrm{XN}_{2}$ up to 16.6 mole \% (Table 1).

Homogenization of $\mathrm{CO}_{2}\left(\mathrm{ThCO}_{2}\right)$ in types $\mathrm{A}$ and $\mathrm{B}$ inclusions takes place invariably in the liquid state and within a wide range of values $\left(-15.0^{\circ} \mathrm{C}\right.$ to $\left.17.0^{\circ} \mathrm{C}\right)$ in the quartz-feldspathic breccia and quartz-albite-sulphide vein Fig. 5). $\mathrm{ThCO}_{2}$ in type $\mathrm{A}$ inclusions of the quartz-feldspathic beccia show a maximum frequency between $-4.0^{\circ} \mathrm{C}$ and $3.0^{\circ} \mathrm{C}$, whereas $\mathrm{ThCO}_{2}$ in type $\mathrm{B}$ inclusions are scattered and no frequency peak can be recognized. In the quartz-albite-sulphide vein, $\mathrm{ThCO}_{2}$ in types $\mathrm{A}$ and $\mathrm{B}$ inclusions concentrates preferentially between $6.0^{\circ} \mathrm{C}$ and $7.0^{\circ} \mathrm{C}$ and $11.0^{\circ} \mathrm{C}$ and $12.0^{\circ} \mathrm{C}$ respectively (Fig. 5). Contrasting with the above data, $\mathrm{ThCO}_{2}$ in type $\mathrm{B}$ inclusions of the quartz vein defines a narrower range of values $\left(11.0^{\circ} \mathrm{C}\right.$ to $26.0^{\circ} \mathrm{C}$ ), with a maximum frequency between $14.0^{\circ} \mathrm{C}$ and $15.0^{\circ} \mathrm{C}$ (Fig. 5 ).

In order to estimate the minimum trapping temperature of the fluids, high temperature measurements were carried out in type B inclusions to determine their total homogenization temperature (Th). This phenomenon occurs in the gaseous state, but accurate values could not be obtained because of several optical limitations or decrepitation before complete homogenization. The few data available depicted in figure 6 show that $\mathrm{Th}$ values range from $250^{\circ} \mathrm{C}$ to $400^{\circ} \mathrm{C}$ for type $\mathrm{B}$ inclusions, with maximum frequencies around $350^{\circ} \mathrm{C}$ and for the quartz-feldspathic breccia and $250^{\circ} \mathrm{C}$ and $300^{\circ} \mathrm{C}$ for the quartz vein. There are no data available on Th of type B inclusions of the quartz-albite-sulphide vein. Type $C$ inclusions in the quartz-feldspathic breccia and quartz-albite-sulphide vein show Th values between $80^{\circ} \mathrm{C}$ and $120^{\circ} \mathrm{C}$ and are considered as representatives of aqueous fluids which circulated after the main stages of mineralization at higher crustal levels (Fig. 6). In the quartz vein, the Th values for type $\mathrm{C}$ inclusions range from $120^{\circ} \mathrm{C}$ to $400^{\circ} \mathrm{C}$ and define a frequency peak between $220^{\circ} \mathrm{C}$ and $240^{\circ} \mathrm{C}$, close to the frequency peak of the associated type B inclusions (Fig. 6).
MASSIVE QUARTZ VEIN (SB 80 I)

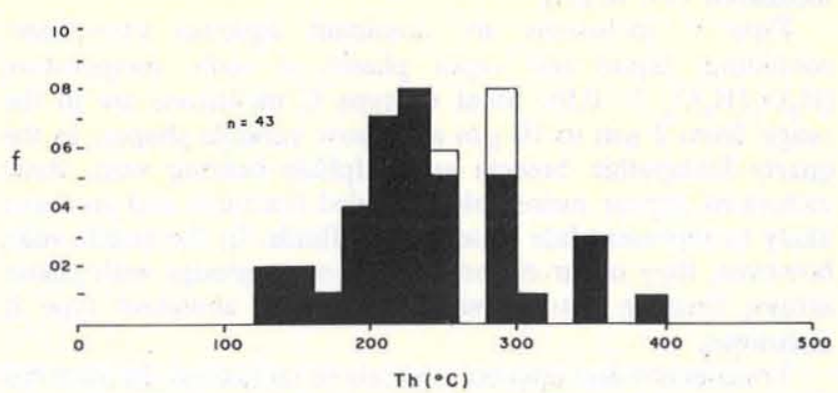

QUARTZ-FELDSPATHIC BRECCIA (GD IV)

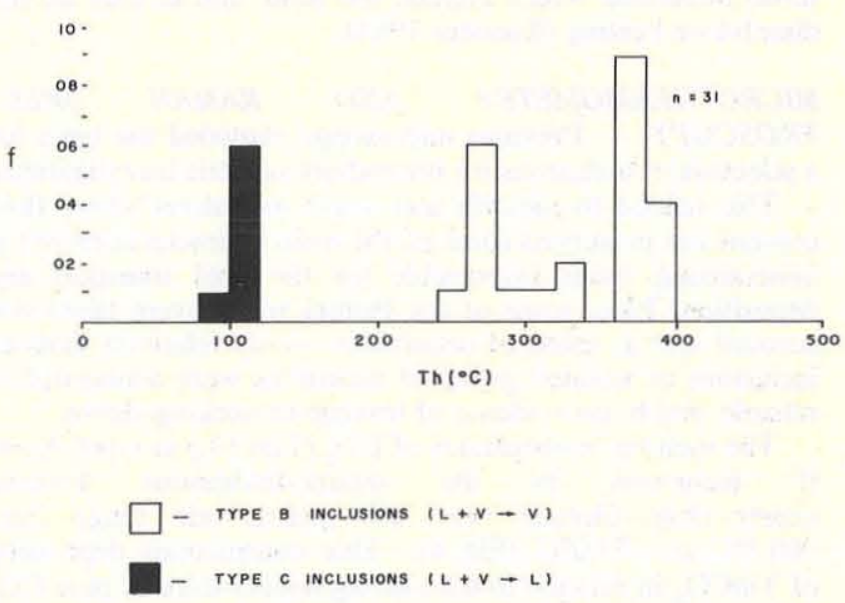

Figure 6 - Total homogenization temperature (Th) $\mathrm{H}_{2} \mathrm{O}-\mathrm{CO}_{2}$ (type B) and aqueous (type C) inclusions in mineralized samples. The legend is the same as in figure 4 

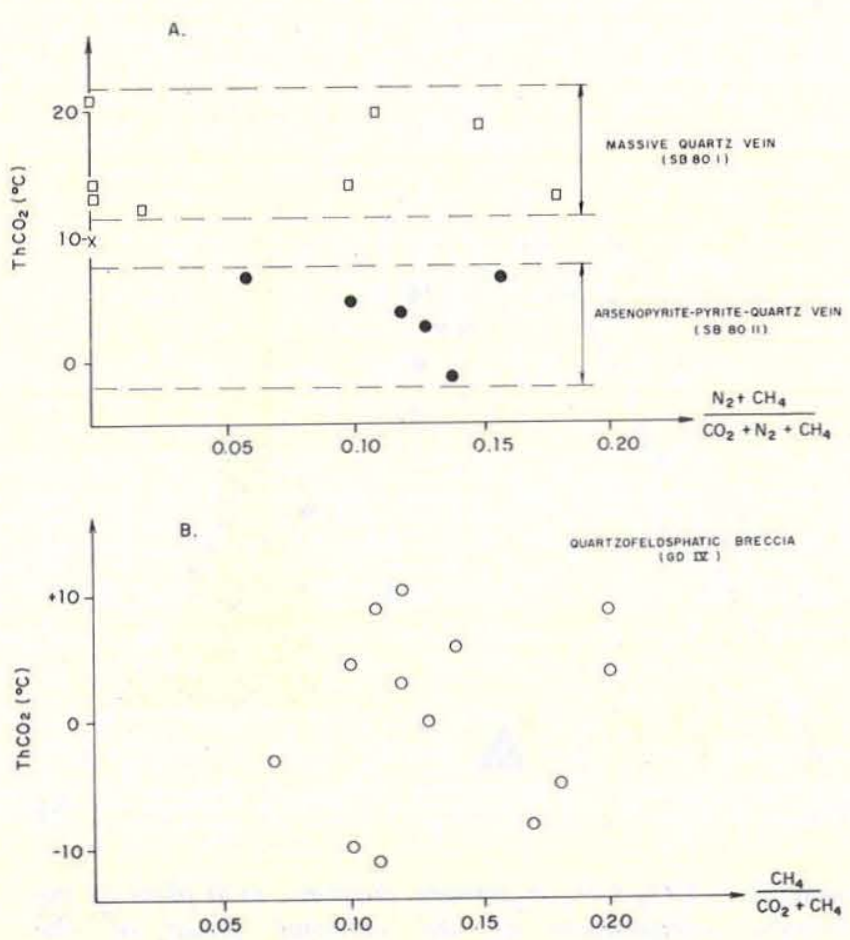

Figure 7 - A. ThCO $\mathrm{O}_{2}$ versus the $\mathrm{N}_{2}-\mathrm{CH}_{4}$ content of types $\mathrm{A}$ and $B$ inclusions in gold-bearing quartz veins; B. ThCO versus the $\mathrm{CH}_{4}$ content of types $A$ and $B$ inclusions in the quartz-feldsphatic breccia

THE RELATIONS BETWEEN MICROTHERMOMETRIC DATA AND THE COMPOSITION OF THE INCLUSION FLUIDS The melting and the homogenization temperatures of a certain group of cogenetic inclusions are important because they provide a close estimate of their chemical composition and an order of magnitude of the density of the fluid likely to have generated them. In ideal conditions, that is, for pure or pure mixed systems $\left(\mathrm{CO}_{2}\right.$, $\mathrm{H}_{2} \mathrm{O}, \mathrm{H}_{2} \mathrm{O}-\mathrm{NaCl}$, and $\left.\mathrm{H}_{2} \mathrm{O}-\mathrm{CO}_{2}\right)$, these two parameters can be well established within a fairly good degree of certainty. However, this is not the rule for most of the geological situations, but rather the exception, since fluid inclusions have been shown to be more chemically complex than pure systems, due to the presence of other components dissolved in the gaseous $\left(\mathrm{CH}_{4}, \mathrm{~N}_{2}, \mathrm{H}_{2} \mathrm{~S}, \mathrm{CO}\right.$, etc. $)$ and aqueous $\left(\mathrm{Mg}^{+2}, \mathrm{Ca}^{+2}\right.$, $\mathrm{K}^{+}, \mathrm{Fe}^{+2 /+3}$, etc.) phases.

The data on the relative amounts of $\mathrm{CH}_{4}$ and $\mathrm{N}_{2}$ dissolved in the carbonic phase of types $\mathrm{A}$ and $\mathrm{B}$ inclusions determined by Laser Raman Microprobe (Table 1) were conbined with microthermometry to assess the influence of these minor components on the $\mathrm{ThCO}_{2}$ as well as determine the chemical system in which the inclusion fluids should be interpreted.

Figure $7 \mathrm{a}$ reveals that despite the large variation in the composition of the inclusion fluids, the $\mathrm{ThCO}_{2}$ of their carbonic phase lies always within a narrow interval. In the case of type $\mathrm{A}$ inclusions of the quartz-feldspathic breccia, plots of $\mathrm{ThCO}_{2}$ versus $\mathrm{CH}_{4}$ content do not yield any definite positive correlation (Fig. $7 \mathrm{~b}$ ).

Two important conclusions can be inferred from the above behaviours: 1. the large range of $\mathrm{CO}_{2}$ homogenization temperatures seen in the histograms is a reflection of fluid density rather than due to any pronounced compositional effects; and 2. since the composition has a minimum (if any) influence on the $\mathrm{ThCO}_{2}$, the minor components dissolved in the carbonic phase of type A and B inclusions can be neglected and their fluid content can be interpreted as pure or pure-mixed systems, as well as their isochores easily calculated.

As a consequence, the isochores and related densities of the inclusion fluids considered as the colsest samples of the

Table 1: Microthermometry and Raman spectroscopic data for types $A$ and $B$ inclusions in the mineralized samples: VCO $V t=$ volume ratio between the carbonic phase and the total volume of the inclusion; $X i=$ molar fraction of substance $\mathbf{i}$ in the inclusion; $\mathbf{d v}$ $=$ density of the $\mathrm{CO}_{2} ; \mathbf{d}=$ global density of the inclusion fluid. The global composition of the carbonic inclusions (type A) was directly obtained by the Raman spectroscopy, whereas for the $\mathrm{H}_{2} \mathrm{O}-\mathrm{CO}_{2}$ inclusions (type B) it was calculated by the method of Ramboz et al. (1985)

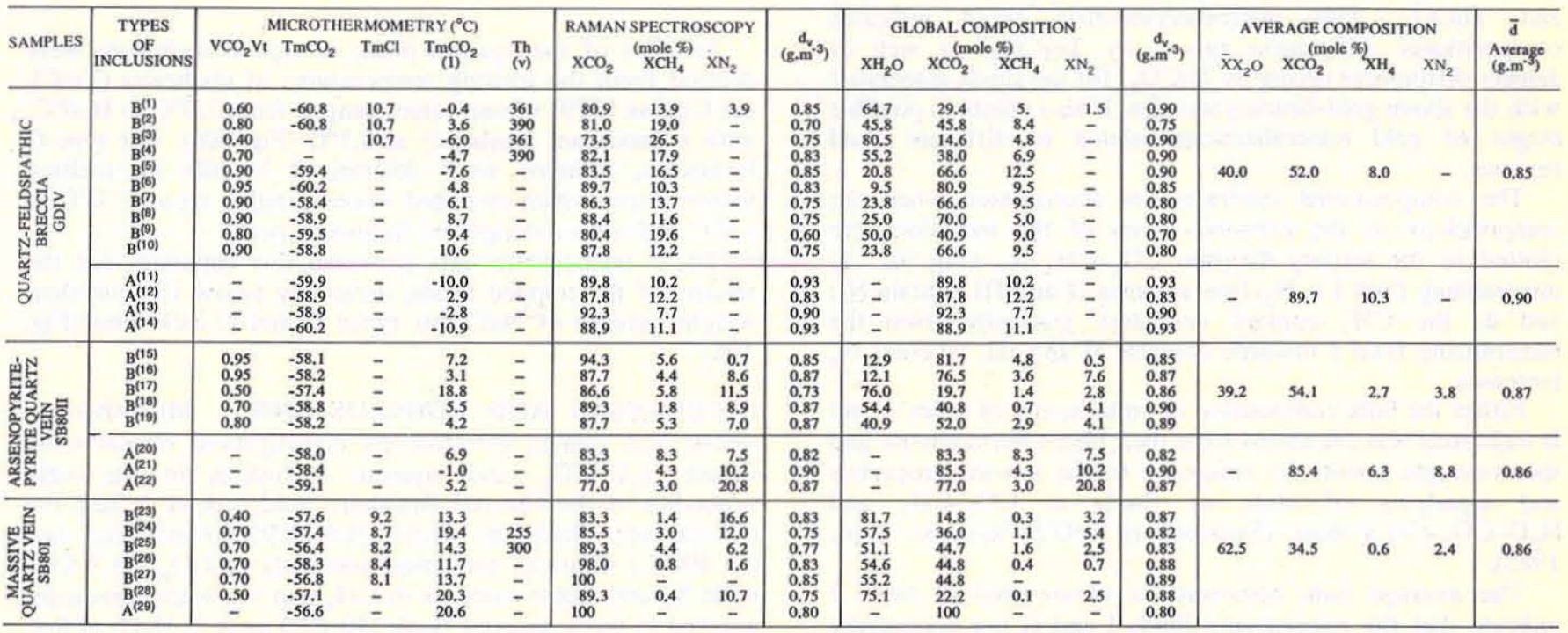


mineralizing fluids in this present work can be found in the $\mathrm{CO}_{2}-\mathrm{CH}_{4}, \mathrm{H}_{2} \mathrm{O}-\mathrm{CO}_{2}-\mathrm{NaCl}$ and $\mathrm{H}_{2}-\mathrm{NaCl}$ systems.

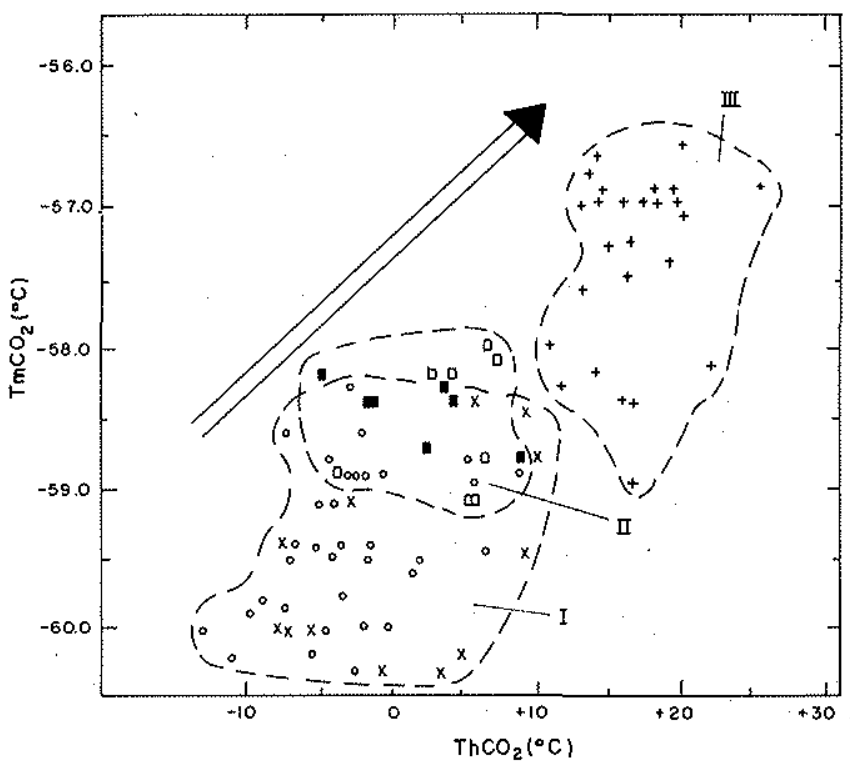

$$
\begin{aligned}
& \text { - TYPE A }] \text { QUARTZ.FELDSPATHIC BRECCIA } \\
& \text { (GD IV) } \\
& \text { - TYPE a ] aRSENOPYRITE-PYRITE-CUARTZ VEIN } \\
& \text { D TYPE } \theta] \text { [SA } 80 \mathrm{li} \text { ) } \\
& \text { + TYPE B] MASSIVE QUARTZ VEIN }
\end{aligned}
$$

Figure 8 - Microthermometric trend of inclusion fluids defined by the relation $\mathrm{TmCO}_{2}$ versys $\mathrm{ThCO}_{2}$ of $\mathrm{A}$ and $\mathrm{B}$ inclusions in the ivestigated mineralized samples. I, II and III: mineralizing fluids

\section{CHARACTERIZATION AND EVOLUTION OF THE} MINERALIZING FLUIDS The relation between melting and homogenization temperatures of $\mathrm{CO}_{2}$ of selected types $\mathrm{A}$ and $\mathrm{B}$ inclusions define a clear microthermometric trend and three distinct domains can be recognized (Fig. 8). Domains $I$ and II corresponding to the quartz-feldspathic breccia and quartz-albite-sulphide vein, with lower $\mathrm{ThCO}_{2}$, and domains III, related to quartz vein with higher $\mathrm{ThCO}_{2}$ and $\mathrm{ThCO}_{2}$. This microthermometric trend indicates compositional differences (given by $\mathrm{TmCO}_{2}$ ) as well as density differences (given by $\mathrm{ThCO}_{2}$ ) for the fluids associated with the above gold-bearing samples. It also points to possible stages of gold mineralizations related to different fluid regimes.

The compositional contrasts are accentuated when the compositions of the carbonic phase of the inclusions are plotted in the ternary diagram $\mathrm{CO}_{2}-\mathrm{CH}_{4}-\mathrm{N}_{2}$ (Fig. 9): 1 . mineralizing fluid $\mathrm{I}$ is $\mathrm{N}_{2}$-free whereas II and III contain $\mathrm{N}_{2}$; and 2 . the $\mathrm{CH}_{4}$ content decreases gradually from the mineralizing fluid I towards domains II and III, whereas $\mathrm{N}_{2}$ increases.

Either the bulk composition or bulk density of types $\mathrm{A}$ and $B$ inclusions was calculated from their microthermometric and spectroscopic results by reference to the known properties and equations of state of fluids in $\mathrm{CO}_{2}-\mathrm{CH}_{4}$ and $\mathrm{H}_{2} \mathrm{O}-\mathrm{CO}_{2}-\mathrm{CH}_{4}$ system (Swanenberg 1979, Ramboz et al. 1985).

The average bulk compositions summarized in table 2 indicate that the mineralizing fluids $\mathrm{I}$ and $\mathrm{II}$ are dominantly $\mathrm{CO}_{2}$-rich (89.7-54.1 mole \% of $\mathrm{CO}_{2}$ ) whereas fluid III has a more aqueous character $\left(62.5\right.$ mole $\%$ of $\left.\mathrm{H}_{2} \mathrm{O}\right)$. The decrease of $\mathrm{CH}_{4}$ and $\mathrm{N}_{2}$ from domains I towards $\mathrm{III}$ is also very apparent

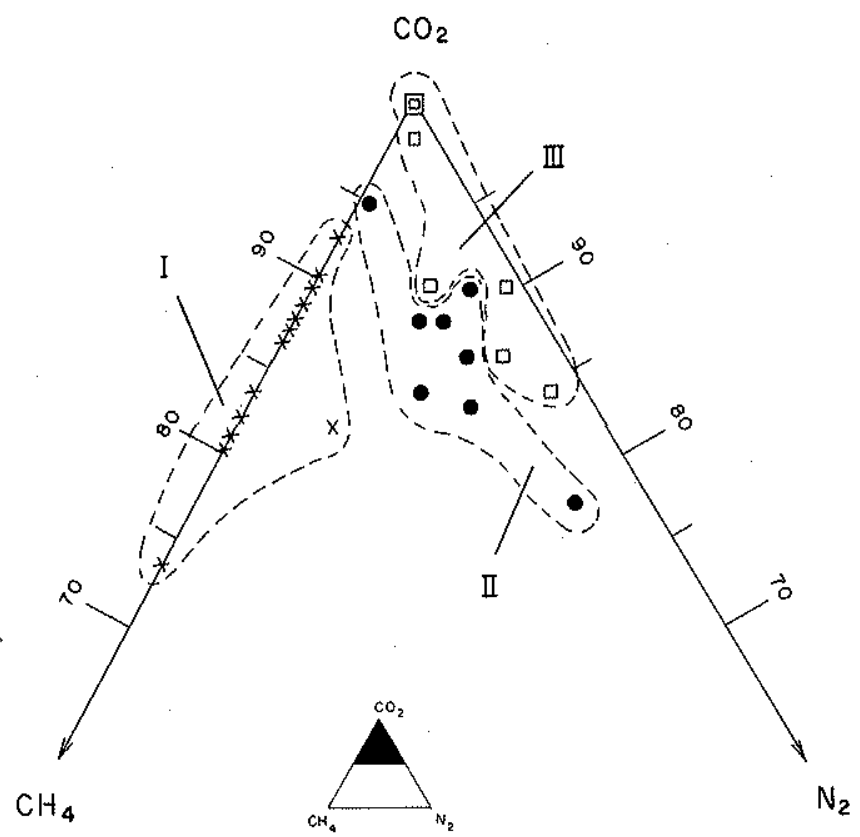

Figure 9-: $\mathrm{CO}_{2}-\mathrm{CH}_{4}-\mathrm{N}_{2}$ ternary diagram, with plots of the ch'mical composition of the carbonic phase of the investigated inclusions obtained by Raman spectroscopy. Note that again mineralizing fluids form three distinct fields $(I, I I$ and III) with contrasting chemical characteristics

\begin{tabular}{|c|c|c|c|c|c|c|c|c|}
\hline \multicolumn{2}{|c|}{$\begin{array}{l}\text { MINERALIZINO } \\
\text { FLUDSS }\end{array}$} & $\underset{\mathrm{H}_{2} \mathrm{O}}{\mathrm{A} \mathrm{O} \text { 的ABB }}$ & $\underset{\mathrm{CO}_{2}}{\mathrm{CHEMICAL}}$ & $\underset{\mathrm{CH}_{4}}{\text { COMPOSITION }}$ & $\left(\operatorname{mol}_{2} x_{0}\right)$ & $\begin{array}{l}\text { AVERAGE } \\
\text { DENSTTY } \\
\text { ( }\left(\mathrm{g}^{\prime} \mathrm{cm}^{3}\right)\end{array}$ & $\begin{array}{c}\text { REPRESENTATIVE } \\
\text { FLUID } \\
\text { INCLUSIONS }\end{array}$ & $\begin{array}{c}\mathrm{TH}\left({ }^{\circ} \mathrm{C}\right) \\
\text { (Noil pressuro } \\
\text { corrected })\end{array}$ \\
\hline 1 & $\begin{array}{l}I_{A} \\
I_{B}\end{array}$ & 40.0 & $\begin{array}{l}89.7 \\
52.0\end{array}$ & $\begin{array}{r}10.3 \\
8.0\end{array}$ & - & $\begin{array}{l}0.90 \\
0.85\end{array}$ & \multirow{2}{*}{$\begin{array}{l}\text { Type A very } \\
\text { abundant } \\
\text { and Only } \\
\text { type B } \\
\text { subordinate }\end{array}$} & \multirow[t]{2}{*}{400} \\
\hline II & $\begin{array}{l}\mathrm{H}_{\mathrm{A}} \\
\mathrm{t}_{\mathrm{B}}\end{array}$ & $\begin{array}{l}- \\
39.2\end{array}$ & $\begin{array}{l}85.4 \\
54.1\end{array}$ & $\begin{array}{l}6.3 \\
2.7\end{array}$ & $\begin{array}{l}8.8 \\
3.8\end{array}$ & $\begin{array}{l}0.86 \\
0,87\end{array}$ & & \\
\hline & III & 62.5 & 24,5 & 0.6 & 2.4 & 0.86 & Type 13 and type C & 250 \\
\hline
\end{tabular}

and has been emphasized elsewhere. The values of the bulk densities of the mineralizing fluids show a relatively constant vilues, in general ranging from $0.85 \mathrm{~g} / \mathrm{cm}^{3}$ to $0.90 \mathrm{~g} / \mathrm{cm}^{3}$.

Table 2 - Global characteristics of the mineralizing fluids

Salinites of the aqueous phase of type B inclusions were derived from the melting temperatures of clathrates $(\mathrm{TmCl}$, see Collins 1979) whose values ranged from $7.0^{\circ} \mathrm{C}$ to $16.0^{\circ} \mathrm{C}$, with a maximum frequency at $8.5^{\circ} \mathrm{C}$ (Fig. 10a). For type $\mathrm{C}$. inclusions, salinites were determined by the ice melting temperatures which provided values ranging from $-5.0^{\circ} \mathrm{C}$ to $1.0^{\circ} \mathrm{C}$ without a recongnized frequency peak.

These temperature data provided low estimates for the salinity of the trapped fluids, invariably below 10 equivalent weight percent of $\mathrm{NaCl}$ for types $\mathrm{B}$ and $\mathrm{C}$ inclusions (Fig. 10b)

DISCUSSION AND CONCLUSIONS Microthermometric and Raman spectroscopy investigations on carbonic, mixed $\mathrm{H}_{2} \mathrm{O}-\mathrm{CO}_{2}$, and aqueous inclusions in the main orebodies of the Fazenda Brasileiro gold deposit defined the mineralizing fluids as dense $\left(0.85-0.90 \mathrm{~g} / \mathrm{cm}^{3}\right)$ and hot $\left(>400^{\circ} \mathrm{C}\right)$ solutions composed essentialy of $\mathrm{CO}_{2}(89.7-85.4$ mole \%) and minor amounts of $\mathrm{CH}_{4}$ and $\mathrm{N}_{2}$, which gradually evolved to more aqueous fluids $\left(40-62.5 \mathrm{~mole} \% \mathrm{H}_{2} \mathrm{O}\right)$ of low salinity $(<10 \mathrm{eq}$. $w t \% \mathrm{NaCl})$ at lower temperatures $\left(250-300^{\circ} \mathrm{C}\right)$. It was also possible to distinguish three groups of mineralizing fluids, namely I, II, and III, with 


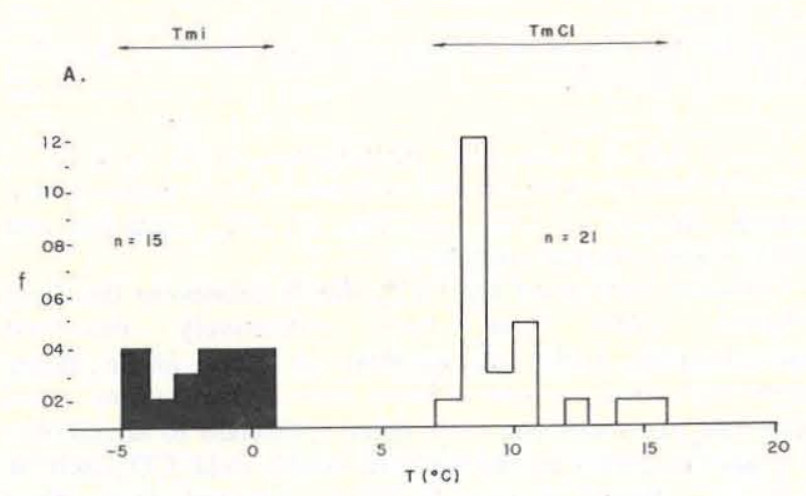

B.

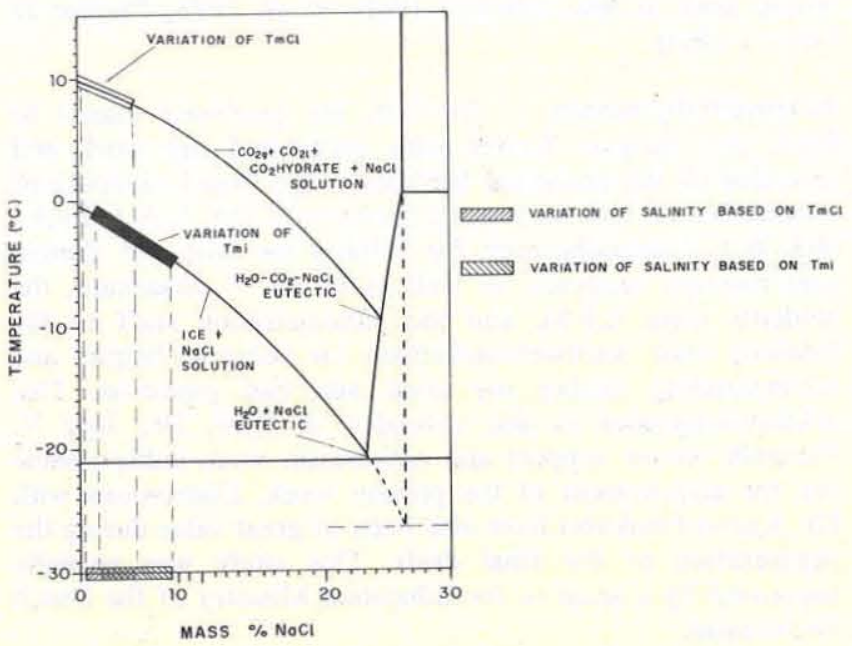

Figure 10 - A. Histogram of melting temperature of clathrates (TmCl) and ice (Tmi) for types $B$ and $C$ inclusions, respectively; $\mathrm{B}$. estimates of the salinity of the mineralizing fluids based on TmCl and Tmi (Collins 1979)

contrasting microthermometric and spectroscopic results (Figs. 8 and 9).

Based on these data, it is conceivable that the transport of gold and its deposition in the quartz-feldspathic breccia and quartz-albite-sulphide vein were carried out by $\mathrm{CO}_{2}-\mathrm{CH}_{4}$ dominant fluids I and II at temperatures above $400^{\circ} \mathrm{C}$. The presence of low salinity $\mathrm{H}_{2} \mathrm{O}-\mathrm{CO}_{2}$ fluids is recognized in very small amounts in these earliest stages of mineralization, demoting a first introduction of $\mathrm{H}_{2} \mathrm{O}$ in the system. This situation is supported by the coexistence of carbonic and mixed $\mathrm{H}_{2} \mathrm{O}-\mathrm{CO}_{2}$ inclusions in the investigated samples. In contrast, the mineralizing fluid III trapped in the quartz vein is water-dominated, colder, low salinity fluid, containing less than 35 mole $\% \mathrm{CO}_{2}$.

Beside composition, density, and salinity, fluid inclusion data also provide information on the minimum pressure and temperature during trapping, except for the case of simultaneous trapping of immiscible fluids $\left(\mathrm{H}_{2} \mathrm{O}\right.$-rich and $\mathrm{CO}_{2}$-rich fluids, boiling fluids, etc., c.f. Roedder \& Bodnar 1980).

Isochores for type $\mathrm{A}$ and $\mathrm{B}$ inclusions in the quartz-feldspathic breccia and quartz-albite-sulphide vein were calculated based on their average compositions and bulk density (Table 2), and the known volumetric properties of $\mathrm{CO}_{2}-\mathrm{CH}_{4}$ and $\mathrm{H}_{2} \mathrm{O}-\mathrm{CO}_{2}-\mathrm{NaCl}$ systems (Swanenberg 1979), Bowers \& Helgeson 1983). In figure 11, the intersection of the isochores corresponding to carbonic fluids with densities of $0.90 \mathrm{~g} / \mathrm{cm}^{3}$ and $0.85 \mathrm{~g} / \mathrm{cm}^{3}$ with the line which denotes the average temperature of total homogenization for type B inclusions $\left(\mathrm{Th}=380^{\circ} \mathrm{C}\right)$ in the quartz-feldspathic breccia and quartz-albite-sulphide vein, establish a minimum range of pressure of $2.2-2.5 \mathrm{~kb}$ for the entrapment of these fluids. Assuming that the pressure effect is negligible (Sharp et al. 1985), the assemblage arsenopyrite + pyrite gives an upper stability temperature of $491^{\circ} \mathrm{C}$. Using this temperature as an upper unit, the isochores define an upper pressure limit between $2.7 \mathrm{~kb}$ and $3.2 \mathrm{~kb}$ (Fig. 11).

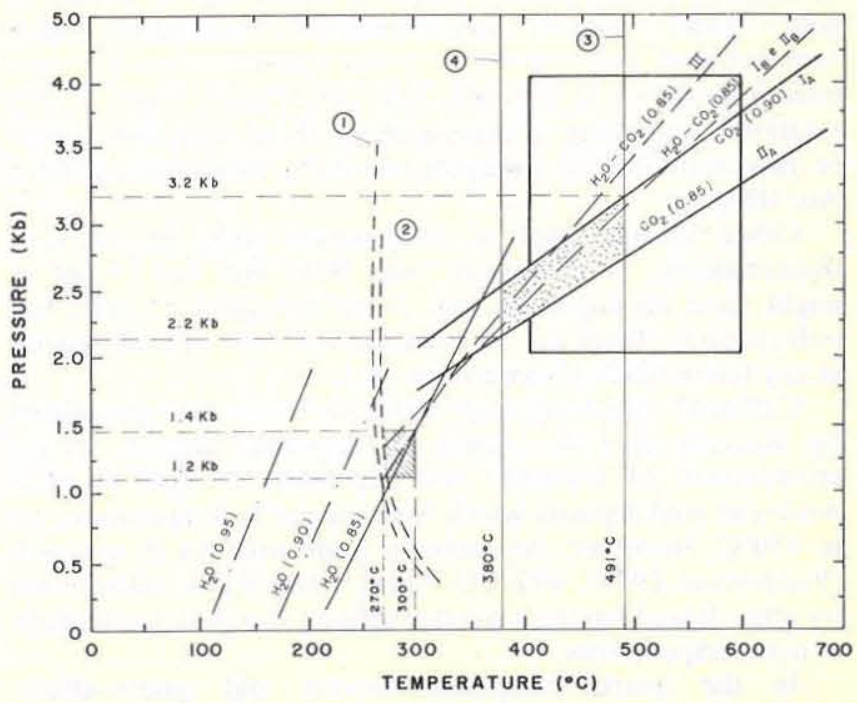

SOCHORES

$\mathrm{CO}_{2}\left(2 \mathrm{CH}_{4}\right)$

$\mathrm{H}_{2} \mathrm{O}-\mathrm{CO}_{2}-\mathrm{NaCl}$ ( $\mathrm{CH}_{4}$, ANO $\mathrm{N}_{2}$ ARE NOT CONSIDEREO?

LOW SALINITY AQUEOUS FLUIDS COEXISTENT WITH FLUIO III

- - late low-salinity aqueous fluios

GOLD MINERALIZATION ASSOCIATED WITH THE QUARTZ-FELDSPATHIC BRECCIA AND ARSENOPYRITE - PYRITE - QUARTZ VEIN

GOLD MINERALIZATION ASSOCIATED WITH THE MASSIVE QUARTZ VEIN

Figure 11 - P-T diagram with the estimated intervals for the two stages of gold deposition (dotted and shaded area). The larger inner rectangle depicts the $P-T$ range of the regional metamorphism defined by Silva (1983), in the mid-portion of the Rio Itapirucu greenstone belt: 1 and $\mathbf{2}=$ critical curves for $\mathrm{H}_{2} \mathrm{O}-30$ mole $\% \mathrm{CO}_{2}$ and $\mathrm{H}_{2} \mathrm{O}-50$ mole \% CC respectively (Bowers \& Helgeson 1983); $3=$ upper thermal limit for arsenopyrite-pyrite stability (not pressure corrected) (Sharp et al. 1985); 4 = average total homogenization temperature (Th) of $\mathrm{H}_{2} \mathrm{O}-\mathrm{CO}_{2}$ inclusions in the quartz-feldspathic breccia

If the coexistence of $\mathrm{H}_{2} \mathrm{O}-\mathrm{CC}_{2}$ and $\mathrm{H}_{2} \mathrm{O}$ inclusions in the massive quartz vein is interpreted in terms of simultaneous trapping at the time of an event of fluid unmixing or mixing, $\mathrm{P}-\mathrm{T}$ conditions can be estimated by the intersection of their isochores (Roedder \& Bodnar 1980). Isochores of these inclusion fluids show a point of intersection at $300^{\circ} \mathrm{C}$ and 1.4 $\mathrm{kb}$, which lies close to the critical curve for $\mathrm{H}_{2} \mathrm{O}+30$ mole\% $\mathrm{CO}_{2}$, at $270^{\circ} \mathrm{C}$ and $1.2 \mathrm{~kb}$ (Fig. 11). These estimates are in accordance with the average total homogenization temperatures of the $\mathrm{H}_{2} \mathrm{O}-\mathrm{CO}_{2}$ inclusions $\left(\mathrm{Th}=250^{\circ} \mathrm{C}\right)$.

The high content of $\mathrm{CC}_{2}$ and the presence of $\mathrm{CH}_{4}$ in the inclusion fluids, the stability of albite rather than muscovite and the close association of gold with sulphides, notably arsenopyrite and pyrite, in the advanced hydrothermal alteration zone (Marimon et al. 1986), suggest neutral to alkalic S-bearing fluids under conditions of low $\mathrm{fO}_{2}$ (high $\left.\Sigma \mathrm{H}_{2} \mathrm{~S} / \Sigma \mathrm{SO}_{4}\right)$ as responsible for the gold solubilization and 
transport. Under the above conditions, thio-complexes as Au $(\mathrm{HS})_{2}^{-}, \mathrm{HAu}(\mathrm{HS})_{2}^{-}$or HAu (HS) ${ }_{2} \mathrm{~S}^{-2}$ are likely to be of most importance in the transport of gold since experimental investigations have shown their high solubility in high temperature neutral to alkalic reduced solutions (Seaward 1982).

Another evidence for the transport of gold by thiocomplexes is provided by the $\mathrm{Ag} / \mathrm{Au}$ ratio which is less than 1 at the Fazenda Brasileiro gold mine. Cole \& Drummond (1986) in the attempt to assess the behaviour of gold under several pre-established conditions have demonstrated that $\mathrm{Ag} / \mathrm{Au}<1$ are attined in low $\mathrm{Cl}^{-1}(0.1$ molar), moderate to high pH, high $\mathrm{\Sigma H}_{2} \mathrm{~S} / \mathrm{\Sigma SO}_{4}$ ratio $\left(>10^{5}\right)$ solutions. According to these authors, these conditions would be favourable for the transport of gold by thiocomplexes such $\mathrm{Au}(\mathrm{HS})_{2}$.

Other ligands, such a thioarsenide $\mathrm{AsS}_{2}$ or $\mathrm{As}_{2} \mathrm{~S}_{4}^{2}$ ), thioantimonite or complexes with $\mathrm{NH}_{3}^{+}, \mathrm{Br}^{-}$and $\mathrm{I}^{-}$and Imight have an important role in the transport of gold, but unfortunately there are no experimental data on such species at any temperature (Seaward op. cit.).

Carbonyl complexes (e.g. AuClCO-) have been postulated by Kerrich \& Fyfe (1981) as important ligands in the environment of transport and deposition of gold in some Archaean gold deposits which have formed at temperatures up to $450^{\circ} \mathrm{C}$. However, the carbonyl bond with $\mathrm{Au}$ (I) is weark (Puddephaat 1978), with $\mathrm{CO}^{-}$being vulnerable to substitution by other ligand having a greater affinity for gold, particularly at high temperatures.

In the quartz-feldspathic breccia and quartz-albitesulphide vein, gold might have precipitated by a decrease in the aS-2 with the deposition of metal sulphides during fluid/ rock reactions, as following (Phillips \& Groves 1982 and 1983):

$\mathrm{FeO}$ (in silicates) $+\mathrm{HAu}(\mathrm{HS})_{2}+1 / 4 \mathrm{O}_{2}=\mathrm{Au}^{\circ}+\mathrm{FeS}_{2}+$
$11 / 2 \mathrm{H}_{2} \mathrm{O}$

$\mathrm{Fe} \mathrm{O}_{2}$ (1) $3 \mathrm{FeS}_{2}+41 / 2 \mathrm{H}_{2} \mathrm{O}$.

In the quartz vein, gold precipitation might have taken place due to fluid with the introduction of $\mathrm{H}_{2} \mathrm{O}$ in the system causing dilution in $\mathrm{CO}_{2}$, decrease in $\mathrm{pH}$, oxidation and destabilization of gold complexes.

Carbonic and mixed $\mathrm{H}_{2} \mathrm{O}-\mathrm{CO}_{2}$ fluids defined in this fluid inclusion study have been extensively described inmetamorphic rocks of medium to high grade facies (Crawford 1981, Touret 1981). Devolatilization of basal sequences of greenstone belts when submitted to amplibolite to granulite facies metamorphism could yield $\mathrm{CO}_{2}$-rich or $\mathrm{H}_{2} \mathrm{O}-\mathrm{CO}_{2}$ fluids similar to those inferred from fluid inclusions and low porosity under metamorphic conditions would lead to low salinities (Fyfe at al. 1978, Phillips \& Groves 1983).

Acknowledgements At first, my profound thanks to Prof. Dr. Jacques Touret who supervised my work and provided all the analytical facilities at the Free University of Amsterdam. I feel very much indebt with Drs. E.A.J. Burke and W.J. Lustennhouwer for helping me with the Raman spectroscopic analyses, as well as to Dr. P. Maaskant, the students from E.P.M. and the administration staff of the Institute voor Aardwetenschappen for being so helpful and understanding during my good and bad moments. This acknowledgement is also extended to Prof. 'Dr. Jose V. Valarelli whose support and enthusiasm were indispensable for the achievement of the present work. Discussions with Dr. Kazuo Fuzikawa have also been of great value during the organization of the final draft. This study was partially supported by a grant of the Education Ministry of the Dutch Goverment.

\section{REFERENCES}

BOWERS, T.S. HELGESON, H.C. 1983. Calculation of the thermodynamic and geochemical consequences of nonideal mixing in the system $\mathrm{H}_{2} \mathrm{O}-\mathrm{CO}_{2}-\mathrm{NaCl}$ on phase relations in geologic systems: metamorphic equilibria at high pressures and temperatures. Amer. Mineral., 68:1059-1075.

BROWN, P.E. \& LAMB, W.M. 1986. Mixing of $\mathrm{H}_{2} \mathrm{O}-\mathrm{CO}_{2}$ in fluid inclusions; geobarometry and Archean gold deposits. Geochim. Cosmochim. Acta, 50:847-852.

COLE, D.R. \& DRUMMOND, S.E. 1986. The effect of transport and boiling on Ag/Au rations in hydrothermal solutions: a preliminary assessment and possible implications of formation of epithermal precious metal ore deposits. J. Geochem. Explor, 25:45-79.

COLLINS, P.L.F. 1979. Gas hydrates in $\mathrm{CO}_{2}$-bearing fluds and the use of freezing data for estimation of salinity. Econ. Geol, 74:1435-1444.

CRAWFORD, M.L. 1981. Fluid inclusions in metamorphic rocks - low and medium grade. In: HOLLISTER, L.S. \& CRAWFORD, M.L. eds. Fluid inclusions: applications to petrology - short course. Mineralogical Association of Canada, 6:157-181.

DHAMELINCOURT, P.; BENI, J.M.; DUBESSY, J.; POTY, B. 1979. Analysis of fluid inclusions by the RAMAN microprobe MOLE. Bull. Minéral., 102:600-610.

DUBESSY, J.; AUDEOUD, D.; WILKINS, R.; KOSTOLANYI, C. 1982. The use of the Raman microproble MOLE in the determination of the electrolytes dissolved in the aqueous phase of fluid inclusions. Chem. Geol., 37:137-150.

FYFE, W.S.; PRICE, N.J.; THOMPSON, A.B. 1978. Fluids in the Earth's crust. Amsterdam, Elsevier. 383p.

GROVES, D.J. \& PHILLIPS, G.N. 1987. The genesis and tectonic control on Archaean gold deposits of the Western Australian Shield - A metamorphic replacement model. Ore Geology Reviews, 2:287-322.

KERRICH, R. \& FYFE, W.S. 1981. The gold-carbonate association: source of $\mathrm{CO}_{2}$ and $\mathrm{CO}_{2}$ fixation reactions in Axchean lode deposits. Chem. Geol., 33:265-294.

KISHIDA, A. 1979. Caracterizaçđ̃o geológica e geoqutmica das seqüências vulcano-sedimentares do Médio Rio ltapicuru, Bahia. Salvador, 106 p. (Dissertação de Mestrado, Universidade Federal da Bahia).
KISHIDA, A. \& RICCIO, L. 1980. Chemostratigraphy of lava sequences from the Rio Itapicuru Greenstone Belt, Bahia. Precambrian Res. 11:161-178.

MARIMON, M.P.C.; KISHIDA, A.; TEIXEIRA, J.B.G. 1986. Estudo da alteraçäo hidrotermal relacionada à minexalizaçăo aurffera na Mina Fazenda Brasileiro (BA). In: CONGR, BRAS, GEOL., 34, Goiânia. 1986, Anais... Goiânia. SBG. v. 4. 1556-1570.

MONTES LOPES, C.A. 1982. Algumas caracteristicas geológicas $e$ geoquf́micas das mineralizaçóes de ouro na Grea da Jazida da Fazenda Brasileiro, Bahia Salvador, 99 p. (Dissertação de Mestrado, Universidade Federal da Bahia).

PHILLIPS, G.N. \& GROVES, D.I. 1981. Sulphur isotope compositions and genesis of Archean gold mineralization in Australia and Zimbabwe. In: FOSTER, R.P. ed. Gold' 82: The geology, geochemistry and genesis of gold deposits. Rotterdam, Balkema. p. 373-387. (Geol. Soc. Zimbabwe, Spec. Publ. 1).

PHILLIPS, G.N. \& GROVES, D.I. 1983. The nature of Archaean gold-bearing fluids as deducted from gold deposits of Western Australia. Geol Soc.Aust.J., 30:25-39.

POTY, B.; LEROY, J.; JACHIMOWICZ, L. 1976. Un nouvell appareil pour la mesure des temperatures sous le microscope: l'installation de microthermometric CHAIXMECA. Boll. Soc. Fr. Minéral. Cristallogr., 99:182-186.

PUDDEPHATT, R.J, 1978. The chemistry of gold. Amsterdam. Elsevier $274 \mathrm{p}$

RAMBOZ, C.; SCHNAPPER, D.; DUBESSY, J. 1985. P.V-T-X- $\mathrm{fO}_{2}$ evolution of $\mathrm{H}_{2} \mathrm{O}-\mathrm{CO}_{2}-\mathrm{CH}_{4}$-bearing fluid in a wolframite vein: reconstruction from fluid inclusion studies. Geochim. Cosmochim. Acta, 49:205-219.

ROEDDER, E. \& BODNAR, R.J. 1980, Geologic pressure determinations from fluid inclusion studies. Ann. Rev. Earth Planet. Sci., 8:263-301.

ROEDDER, E. 1984. Fluid inclusions. Mineralogical Society of America. Reviews in Mineralogy, 12:644 p.

ROSASCO, G.J.; ROEDDER, E.; SIMMONS, J.H, 1975. Laser activated RAMAN spectroscopy for nondestructive partial analysis of individual phases in fluid inclusions in minerals. Science, 190: 557-560. 
SEAWARD, T.M. 1982. The transport and deposition of gold in hydrothermal systems. In: FOSTER, R.P. ed. Gold 82: The geology, geochemistry and genesis of gold deposits. Rotterdam, Balkema. p. 53-70. (Geol. Soc. Zimbabwe. Spec. Publ. 1)

SHARP, Z.D.; ESSENE, E.J.; KELLY, W.C. 1985. A re-examination of the arsenopyrite geothermometer: pressure considerations and applications to natural assemblages. Can. Mineral, 23:517-534.

SILVA, M.G. 1983. A seqüência vulcano-sedimentar do médio Rio Itapicuru, Bahia: caracterizaçâo petrográfica, consideraçỏes petrogenéticas preliminares e zoneografia metamórfica. Salvador 88 p. (Dissertação de Mestrado, Universidade Federal da Bahia).

SILVA, F.C.A. \& MATOS, F.M.V. 1987. Caracterização e evoluçāo da zona de cisalhamento aurffera da Area Antas, "Greenstone Belt" do Rio Itapicuru, Bahia, Brasil. In: Simp. Estudos Tectônicos, 1, Salvador, 1987. (in press).

SMITH, T.J.; CLOKE, P.L.; KESLER, S.E. 1984, Geochemistry of fluid inclusions from the McIntire-Hollinger Gold Deposit, Timmis, Ontario, Canada, Econ. Geol.; 79:1265-1285.

SWNENBERG, H.E.C. 1979. Phase equilibria in carbonic systems and their application to freezing studies of fluids inclusions. Contr. Min. Petrol., 68:303-306.

TEIXEIRA, J.B.G. 1984. Geologia e controles da mineralizaçāo aurffera em Fazenda Brasileiro, Serrinha (BA). 88. p. (Dissert. Mestrado, Universidade Federal da Bahia).

TEIXEIRA, J.B.G.; SILVA, M.G.; COSTA, U.R.; OLIVEIRA, M.A.; FRATIN, O.; TELES, P.J.; VIANNA, J.A.; GAMA, H.B. 1982.
Rio Itapicuru Greenstone Belt (Serrinha Region) with Faixa Weber Gold Deposits and Serra de Jacobina Gold-Bearing metasedimentary sequence. In: INT. SYMP. ARCH. EARLY PROT. GEOL. EVOL. \& METALLOGENESIS, (ISAP), Salvador, 1982. Excursion Guide... Salvador, SME/BA. p. 118-138.

TEIXEIRA, J.B.G.; KISHIDA, A.; MARIMON, M.P.C.; XAVIER, R.P.; McREATH, I. 1988. The Fazenda Brasileiro gold deposit, Rio Itapicuru, Bahia: Geology, hydrothermal alteration and fluid inclusion studies. Econ. Geol. (in press).

TOURET, J. 1981. Fluid inclusions in high-grade metamorphic rocks. In: HOLLISTER, L.S. \& CRAWFORD, M.S. eds. Fluid inclusions: applications to petrology - short course. Mineralogical Association of Canada, 6:182-208.

XAVIER, R.P. 1987. Estudos de inclusöes fluidas na Mina de Ouro Fazenda Brasileiro, Greenstone Belt do Rio Itapicuru, Bahia, San Paulo, 142 p. (Dissert. estação de Mestrado, Universidade de São Paulo).

WOPENKA, B. \& PASTERIS, J.D. 1986. Limitations to quantitative analysis of fluid inclusions in geological samples by Laser Raman Microprobe Spectroscopy. Applied Spectroscopy, 148:144-151.

MANUSCRITO 535

Recebido em 26 de abril de 1988. Revisáo aceita em 11 de agosto de 1988.

\section{NOTÍCIAS}

\section{ESCUELA LATINOAMERICANA DE QUIMICA INORGÂNICA}

Quanto da realização do segundo encontro de Química Inorgânica, em Santiago (Chile), em dezembro de 1987, e do I Congresso Interamericano, em maio de 1988, em Jalapa (México), foi decidido iniciar a organização da Escuela Latinoamericana de Química Inorgânica, cujo primeiro encontro dar-se-á ao final deste ano, na cidade do México.

Entre os objetivos da "Escuela" destacam-se os de fomentar o conhecimento mútuo dos químicos inorgânicos da região, suas linhas de pesquisa, sua infraestrutura disponível e as experiências em desenvolvimento na área de Química Inorgânica.
Os organizadores desejam organizar um diretório com nomes e endereços de pesquisadores e docentes na área. Os interessados devem escrever para:

Dr. José Antonio Chamizo División de Estudios de Posgrado Faculdad Nacional Autónoma de México 04510 México D.F. 